\title{
SMEs, Wealth Creation and Poverty Alleviation in Nigeria
}

\author{
Olalekan Usiobaifo Asikhia \\ Graduate School of Business Leadership, University of South Africa, South Africa \\ olalekanasikhia@yahoo.com
}

\begin{abstract}
Most developing countries see small and medium-scale enterprises (SMEs) as engines of development, and as such formulate policies that could encourage their establishment and survival. However, in spite of the enormous number of such firms established and operating, the Nigerian economy is still far from being buoyant. This article reports on research testing the wealth creation model applicable to SMEs and investigated the contribution of SMEs to poverty alleviation in Nigeria. A survey of 581 SMEs was conducted and the findings revealed that only $15 \%$ of wealth created that contributed to alleviating poverty was traceable to SMEs. This increased to $24 \%$ when moderated with wealth distribution, but by only one percent when moderated by wealth motivation. This implies that although most SME operators in Nigeria have personal motivations to acquire wealth, they are not distributing it, hence the low percentage of wealth that SMEs contribute to poverty alleviation. Policy implications and recommendations were made.
\end{abstract}

Keywords: Wealth creation model, wealth distribution, wealth motivation

\section{Introduction}

Small and medium-scale enterprises (SMEs) have been established as the driver of most economic growth in many nations of the world (Kapurubandara \& Lawson, 2006). It is also established that about $56 \%$ of employment was generated by new SMEs across Organisation for Economic Co-operation and Development (OECD) countries. Nearly all the jobs created in the United States of America between 1977 and 2005 were created by new SMEs (OECD, 2006). Ten percent of growing SMEs in France, Italy, the Netherlands, Greece and Spain created about 60 to 90 percent of gross employment gains over a period of five to ten years (OECD, 2002). Data from India's SMEs Resource Centre (2012) shows that there are about 30 million SMEs and those 12 million persons are expected to join the workforce by 2015. Flowing from the enormous relevance of SMEs to nations' growth and development, it is expected that Nigerian firms employ over 31 million people with SMEs, accounting for over $80 \%$ of enterprises that employ about $75 \%$ of the Nigeria's total workforce (UNIDO, 2012), should effect a considerable reduction in the country's poverty incidence. Instead, a recent World Bank report rated the Nigerian economy as the largest in Africa, yet is the first among the tenth poorest nations in the world (World Bank, 2014). Literature has shown that poverty is on the increase in Nigeria; $15 \%$ of the Nigerian population were poor before 1965. This increased to 28\% by 1965 and about thirty years later it rose to 66\%. A recent World Bank index places it at 71.5 per cent (World Bank, 2014).

This paper hopes to determine the relationship between SME wealth creation and poverty reduction in Nigeria, to identify the major determinants of such wealth creation and to relate living conditions to wealth created. The translation of wealth created by SMEs into general poverty reduction follows the theoretical pathway of the need achievement theory by McClelland (1961). The theory stipulates that people are motivated by the need to make something out of nothing (Johnson, 1990). Furthermore, achievement motivation is a psychological concept related to venture creation and operations (Shaver \& Scott, 1991). In addition, Enderle (2006) suggests that it is important to know what motivates an individual or firm to create wealth, because the distributive dimension is affected by individual's/firm's motivation for creating wealth. Atkinson and Brandolini (2010), Fosu (2010), Santos-Pautino (2012) and Asikhia (2013) note that it is only when wealth created is distributed that it could alleviate poverty. It is thus important to establish the moderating effects of motivation and distribution on the wealth creation model apart from finding out its relationship with poverty alleviation. This study contributes to the literature on SMEs in the following areas: it evaluates the determinants of the wealth creation model applicable to SMEs in order to show how organisational factors and entrepreneurial factors determine the wealth created by SMEs. Secondly, it 
establishes the effects of SME wealth creation on poverty alleviation in Nigeria. Thirdly, it measures the moderating effects of wealth motivation and distribution on the relationship between SME wealth creation and poverty alleviation. Finally, there is an extension of knowledge about entrepreneurship generally and SME wealth creation in developing countries in particular.

\section{Theoretical framework}

The early theories that explained SME wealth creation and its link with poverty alleviation are the resourcebased view theory (Penrose, 1959), need achievement theory (McClelland, 1961), theory of proportionate growth (Gibrat, 1931) and the "trickle-down" theory of Anderson (1964). Relevant also to the theoretical framework is the concept of need for achievement. Penrose's (1959) resource-based view theory suggests that firms' wealth creation is dependent on the amount of resources available to the firm. A firm with resources will create wealth more rapidly than one with limited access. The availability of resources and the capability to put them to use determine the extent of wealth created by SMEs. The theory of proportionate growth relates the size of a firm to its growth rate, and postulates that these two aspects are independent (Gibrat, 1931). It emphasises that proportionate growth leads to a distribution that is log-normal, that causes it to be motivated by shocks (Sutton, 1990). One such shock could be an injection of new ideas or resources. The more an SME witnesses such shocks, the more it grows in sustainable income with which the wealth is created (Ireland et al., 2003). The law of proportionate growth thus emphasises that as the growth of SMEs increases, the poverty level decreases.

This phenomenon was better explained by the "trickle-down" theory of Anderson (1964), predicated on the fact that growth initially benefits the higher income groups and later trickles downward to the lower income groups over time. In the case of an entrepreneur whose business creates wealth, the effect of such wealth tends to trickle down to other family members and the community through wealth distribution. Need for achievement ( $\mathrm{N}-\mathrm{Ach}$ ) refers to the desire for accomplishment which requires setting and meeting high standards of achievement. N-Ach enables an individual to succeed, and such an individual always seeks improvements and ways of doing things better. This means entrepreneurs with a high N-Ach will not only create wealth, but also translate such wealth into alleviating poverty. Research into the growth of SMEs has been reported on by a number of authors (Adekunle, 2011; Almus, 2002; Anderson \& Tell, 2009; Barkham, Gudgin \& Hart, 1990; Biesebroeck, 2005; Brown, Earle \& Lup, 2005; Hamilton, 2012; Hansen \& Hamilton, 2011; Keeble, 2003; Kotey, 2005), yet there is dearth of literature concerning SME wealth creation and its effects on poverty alleviation. However, Asikhia and Jansen van Rensburg (2015) reviewed large volumes of literature on SMEs and developed a conceptual model of the variables that determine SME wealth creation. This research tests their model empirically while relating the wealth created by SMEs to poverty alleviation.

Hypotheses development: SME wealth creation was operationalised by using the analytical categories of human resources, technology, innovation and creativity, unit cost economies, organisational infrastructure and strategy, while poverty alleviation was measured by the living conditions of entrepreneurs previously and at present. The moderating variables of wealth distribution and wealth motivation were drawn from Anderson's (1964) “trickle-down” theory and McClelland's (1961) need for achievement theory.

Human resources: Data were gathered on knowledge (measured by relevant educational level and experience) and skills (measured by cognate abilities and special skills). Past research on the relevance of human resources to the performance of SMEs revealed a positive relationship (Bharadwaj \& Menon, 2000; Hambrick \& Mason, 1984; Muller \& Gangl, 2003; Piva \& Vivarelli, 2009; Rosli \& Mahmood, 2013). Storey's (2004) study found that it is the first major resource in competition and it plays the decisive role in the allocation and use of resources for enterprise production and business operation that guarantee growth. Hambrick and Mason's (1984) study revealed that the knowledge and abilities of employees are directly related to education, which is critical in making vital decisions (Muller and Gangl, 2003). It is thus hypothesised that:

H1a: CEOs' expertise of SMEs is positively associated with wealth creation.

H1b: CEOs' level of education and previous experience associate positively with wealth creation.

H1c: CEOs' cognate abilities and special skills associate positively with wealth creation. 
Technology adoption: Technology has the ability to create competitive advantage by satisfying the customers better (Walton, Akselsen \& Pitt, 1998). This was measured by information acquisition and information use. The firm's technological capability is the ability to exploit modern technology, and Pietrobelli (2006) sees it as the skill - technical, managerial, or organisational - that enables firms to efficiently use equipment and information, and to improve on the technology. However, technology infrastructure may not be sufficient to sustain competitive advantage; as competitors get knowledgeable about the technology, the initial advantage of the firm is evened out (Bakos, 1991). Rather, the key asset is the technological skills possessed by the managers and their ability to see information (its acquisition and use), which leads to the fourth, fifth and sixth hypotheses:

H2a: Technology adoption is positively associated with SME wealth creation.

$\mathrm{H} 2 \mathrm{~b}$ : Acquisition of knowledge is positively associated with SME wealth creation.

H2c: Use of knowledge acquired is positively associated with SME wealth creation.

Innovation and creativity: Innovation and creativity interrupt the existing market structure through creative destruction to produce new products and services (Schumpeter, 1934). Researchers have also pointed out that a company can only beat its rivals if it does things differently (Chang, Chen, Lin \& Gao, 2012; Newbert, 2007; Porter, 1996; Teece \& Pisano, 1994). Innovativeness has been found to relate positively with firm performance (Chang et al., 2012; Casillas and Moreno, 2009; Lumpkin \& Dess, 1996) Organisations tend to enhance innovation and creativity through licensed intellectual property, degree of customer and employees' involvement in decision making as well as networking and collaboration (Thaennin, Visuthismajam \& Sutheravut, 2012; Chesbrough, 2006, 2003; EIRMA, 2004), which leads to our seventh, eighth, ninth and tenth hypotheses:

H3a: Innovation and creativity associate positively with SME wealth creation.

H3b: Licensed intellectual property associates positively with SME wealth creation.

H3c: Degree of customer and employee involvement in decision making associate positively with SME wealth creation.

H3d: Network and collaboration associate positively with SME wealth creation.

Unit cost economies: The unit cost economies are comprised of the economies of scope and scale. Economies of scale result when an increase in output leads to a decrease in average cost. At a constant capacity, the managerial cost of increasing output can be expected to be low. Economies of scope may arise from either cost complementarities that may be generated between different output categories or the spreading of common costs over an expanded product mix (Tovar and Wall, 2012). SMEs may not be able to immediately take advantage of economies of scope because most of them start small, it will have a positive effect on performance later on. The degree to which they can utilise economies of scale depends on the number of the target customers and the feasibility study. This leads to our eleventh, twelfth and thirteenth hypotheses:

H4a: Unit cost economies associate positively with SME wealth creation.

$\mathrm{H} 4 \mathrm{~b}$ : Economies of scale associate positively with SME wealth creation.

H4c: Economies of scope associate positively with SME wealth creation.

Organisational infrastructure: Organisational infrastructure is comprised of organisational structure (measured by span of control, level of hierarchy and spread of activities), routine and processes (measured by flexibility, agility and degree of integration). Organisations succeed when they are isomorphic with the institutional environment in which they operate (Meyer and Rowan, 1977). Organisations' survival has been found to also depend on the fit between their structures and activities. Organisations built around efficiency need to ensure a fit between structures and activities, and enforce compliance through inspection, monitoring and evaluation of various units' efficiency and unification, and coordination of goals (Kraus, Kauranen \& Reschke, 2011; Analoni \& Karami, 2003). In assessing the determinants for choice of an organisational structure, Kraus et al. (2011) affirm that the structure an organisation adopts depends on its size. Hence the size of SMEs could be said to enhance their agility and flexibility, which in turn aid performance (Cassell, Nadin, Gray \& Clegg, 2002; Kraus et al., 2011; Robbins, 2000). Organisational processes and routines also affect organisational flexibility (Makadok, 2001). It is thus hypothesised that:

H5a: Organisational infrastructure associates positively with SME wealth creation.

H5b: Organisational structure associates positively with SME wealth creation.

H5c: Organisational processes and routines associate positively with SME wealth creation. 
H5d: Flexibility associates positively with SME wealth creation.

H5e: Agility associates positively with SME wealth creation

H5f: Level of integration associates positively with SME wealth creation.

Strategy: The literature reveals that four major strategies are linked with SMEs: product differentiation (Kraus et al., 2011; Minarik, 2007; Barney \& Hesterley, 2006; Cravens \& Piercy, 2006; Jaquier, 2003; Calori \& Ardisson, 1988), strategic entrepreneurship (Hitt, Ireland, Sirmon \& Trahms, 2011; Kuratko \& Audretsch , 2009; Wickham, 2006; Ireland, Hitt \& Sirmon, 2003), niche strategy (Cassell et al., 2002; Lee, Lim, Tan \& Wee, 2001; Bamford, Dean \& McDougall, 1997) and cost parity (Garfamy, 2012; Furubotn \& Richter, 2000; Uzzi, 1997; Nooteboom, 1993; Powell, 1990; Willamson,1975, 1979). Borch, Huse \& Senneseth (1979) and Kraus et al. (2011) recommend that SMEs follow differentiation strategy by providing a special advantage (e.g. quality leadership) that is highly valued by the customers. The major measuring items or indicators for product differentiation are the level of creativity, basic research skills, the firm's product features relative to industry, product complexity and consumer marketing (Asikhia \& Jansen van Rensburg, 2015). The critical components of strategic entrepreneurship are the ability to seek opportunities, the ability to seek advantage, risk acceptance, growth orientation and vision (Hitt et al., 2011; Kraus et al., 2011). Lee et al. (2001) and Bamford et al. (1997) recommend a niche strategy for SMEs, particularly in those segments that are neglected by the larger competitors because of the size of the SMEs and resource capability compared to the larger companies. The use of niche strategy by the SMEs facilitates optimum resource allocation and the establishment of market position (Bello \& Ivanov, 2014). The degree of an SME's niche marketing strategy is measured by product/service features relative to industry leaders and percentage of market share relative to that of large firms. Flowing from the concept of resource poverty, Kraus et al. (2011) assert that SMEs hardly ever achieve cost advantages because they lack some unit cost economies. As a result cost parity is suggested for SMEs, and the major components are the transaction and production costs (Garfamy, 2012; Furubotn \& Richter, 2000; Willamson, 1981, 1979). Hypotheses were thus generated to assess the contribution of each of these strategies to SME wealth creation:

H6a: Strategy associates positively with SME wealth creation.

H6b: Product differentiation associates positively with SME wealth creation.

H6c: Strategic entrepreneurship associates positively with SME wealth creation.

H6d: Niche strategy associates positively with SME wealth creation.

H6e: Cost parity associates positively with SME wealth creation.

H6f: Opportunity-seeking abilities associate positively with SME wealth creation.

H6g: Advantage-seeking abilities associate positively with SME wealth creation.

Poverty alleviation: Data were gathered on the living conditions of entrepreneurs previously and at present to determine the degree of poverty alleviation. Previous research made use of this method to evaluate poverty alleviation (e.g. Roodman \& Morduch, 2009; Bhuiyan, Siwar \& Talib, 2012 and Bhuiyan, Siwar, Islam \& Rashid, 2012). Flowing from McClelland's (1961) need for achievement theory, the entrepreneur's living condition changes as the business makes profit, and this is sustained. It is thus hypothesised that:

H7: Poverty alleviation associates positively with SME wealth creation.

Wealth distribution: Anderson's (1964) "trickle-down" theory explains that as entrepreneurs create wealth; its effect tends to trickle down to less fortunate members of the community. This was corroborated by Enderle (2006), who asserts that wealth alleviates poverty more when it is distributed. It is hypothesised that:

H8: The relationship of poverty alleviation with SME wealth creation is positively moderated by wealth distribution.

Wealth motivation: McClelland (1961) was selective about characteristics and attitudes of achievementmotivated people. This creates the impression that not all motivated people could achieve or accomplish certain objectives, particularly when it does not align with their source of motivation. It is hypothesised that: H9: The relationship of poverty alleviation with SME wealth creation is positively moderated by wealth motivation. 
Enderle (2006) suggests that it is important to know what motivates an individual or firm to create wealth, because the distributive dimension is affected by individual's/firm's motivation for creating wealth. Atkinson and Brandolini (2010), Fosu (2010), Santos-Pautino (2012) and Asikhia (2013) note that it is only when wealth created is distributed that it could alleviate poverty. It is hypothesised that:

H10: Wealth distribution is positively associated wealth motivation.

Figure 1: The research model

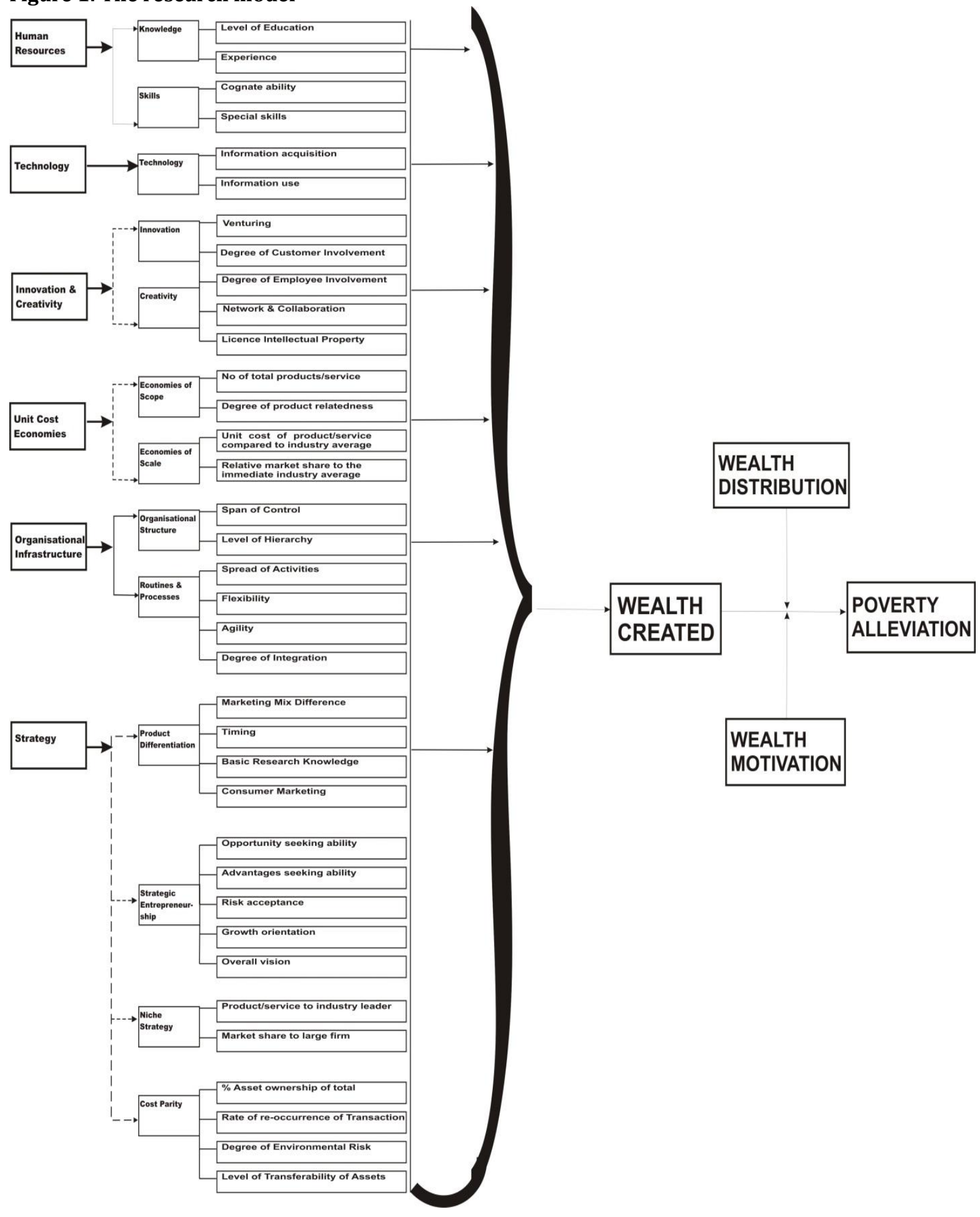




\section{Methodology}

Research context: The Nigerian authorities are not oblivious of the poverty situation of the nation, nor of the operating environment of SMEs. In the light of the poor performance of the Nigerian economy and the inability of various policies to provide visible changes in both micro and macro-economic variables of the economy, policy makers are still hopeful that SMEs' performance should be able to drive the economy. Studies by UNIDO-Nigeria (2012) show that SMEs have the propensity to drive the Nigerian economy, and reveals that currently Nigerian firms employ over 31 million Nigerians and SMEs account for over $80 \%$ of enterprises. The present study thus evaluated the wealth creation capacity of these SMEs and the contribution to poverty alleviation in Nigeria. The Central Bank of Nigeria (2012) defines SMEs as firms of 100 employees or less with an annual turnover of not less than N500, 000.

Sample and data collection: A survey research design was adopted with responses from the CEOs of 581 Nigerian SMEs. The CEOs completed a questionnaire between March and May 2, 2015. Due to the lack of a single public register of SMEs in Nigeria (Asikhia, 2010; Dugguh, 2013) the survey population was drawn from multiple sources of business listings (the Small and Medium Scale Development Agency of Nigeria [SMEDAN], the Nigerian Small and Medium Scale Association [NASMA], and the CAC Business Directory). The survey response rate was 58.1 percent. The CEOs who completed the questionnaire were located in the three main regions of Nigeria, with two states purposely selected from each of the regions based on the poverty level and degree of commercial activities; in the north, Sokoto and Niger, in the east, Ebonyi and Abia, and in the west, Ogun and Lagos.

Data analysis: The data were analysed using the linear regression to test the hypotheses and structural equation modelling for the path dependencies.

Variables: Variables and their measures were drawn from the SME wealth creation model of Asikhia and Jansen van Rensburg (2015). Wealth created by firms was measured by increase in income, increase in physical assets, investments, product line expansion, increase in working capital and enhancement of intellectual capability. Other variables and their measures were human resources (knowledge, level of relevant education, experience, skills, cognate ability and special skill), technology (information acquisition and use), innovation and creativity (venturing, licensed intellectual property, degree of customer involvement, degree of employee involvement, and network and collaboration), unit cost economies (economies of scale, unit cost of product/service compared to the industry average, market share relative to the immediate industry average), organisational infrastructure (organisational structure: span of control, level of hierarchy and spread of activities), routines and process (flexibility, agility and degree of integration), strategy (product differentiation, marketing mix difference, timing, basic research knowledge), consumer marketing, strategic, entrepreneurship (opportunity-seeking abilities, advantage-seeking abilities, risk acceptance, growth orientation and overall vision), niche strategy (product/service features compared to industry leader, market share to large firms), and cost parity (percentage of asset ownership of total, rate of re-occurrence of transaction, degree of environmental risk and level of transferability of assets). Poverty alleviation was measured by the degree to which entrepreneurs are able to meet their personal, family and community obligations. Wealth distribution was measured with indices like payment of staff salaries, rendering help to members of immediate and extended families, helping members of the community, and contributing to community development based on the Anderson's (1964) "trickle-down" theory. The wealth motivation was measured by different indices developed along the line of thoughts of McClelland (1961). The indices providing employment, building a business to pass on, securing a future for family members and the proven ability to do so, personal growth, enjoying excitement, meeting the challenge, gaining public recognition, controlling own employment destiny, being one's own boss, self-employment and maintaining personal freedom were positively scored, while personal security, increasing income opportunities, increasing personal income and acquiring personal wealth were negatively scored. All constructs were measured on a Likert-type scale of five points. All constructs are presented in Table I. The Cronbach's alphas were all above 0.70 .

Controls: It has been pointed out that value creation may vary with firm size and age (Pender, Alexander \& Reeder, 2012; Pitelis \& Vasilaros, 2009). We thus controlled the wealth creation capacity of the firms 
with firm size and age.

Measurement model and validity: The validity of the constructs was tested using confirmatory factor analysis (CFA). All items of human resource components, technology, innovation \& creativity, unit cost economies, organisational infrastructure, firm strategy and poverty alleviation converge well on their latent construct. With good fit indices of chi square (minimum discrepancy)/degrees of freedom $(\mathrm{CMIN} / \mathrm{DF})=1.54$; Comparative Fit Index $(\mathrm{CFI})=0.90$; Root Mean Square Error of Approximation $($ RMSEA $)=0.60$. The model was then compared with other constrained models and it was established that a six-factor model is the best fit for the study.

Table 1: Factor loadings of the construct

\begin{tabular}{|c|c|c|c|c|}
\hline S/N & Major variables & Sub-variables & $\begin{array}{l}\text { Internal } \\
\text { consistency }\end{array}$ & $\begin{array}{l}\text { Composite } \\
\text { reliability }\end{array}$ \\
\hline & \multirow[t]{4}{*}{ Human resources } & Education & 0.83 & 0.84 \\
\hline & & Experience & 0.80 & 0.83 \\
\hline & & Abilities & 0.81 & 0.83 \\
\hline & & Skills & 0.82 & 0.84 \\
\hline & \multirow[t]{3}{*}{ Technology } & Information acquisition & 0.80 & 0.83 \\
\hline & & & 0.81 & 0.83 \\
\hline & & Information use & $\begin{array}{l}0.81 \\
0.79\end{array}$ & $\begin{array}{l}0.83 \\
0.82\end{array}$ \\
\hline & \multirow[t]{4}{*}{ Innovation \& creativity } & $\begin{array}{l}\text { Licensed intellectual } \\
\text { property }\end{array}$ & 0.80 & 0.83 \\
\hline & & Customer involvement & 0.81 & 0.83 \\
\hline & & Employee involvement & 0.80 & 0.83 \\
\hline & & Network \& collaboration & 0.78 & 0.82 \\
\hline & Unit cost economies & $\begin{array}{l}\text { Economies of scale } \\
\text { Economies of scope }\end{array}$ & $\begin{array}{l}0.79 \\
0.80\end{array}$ & $\begin{array}{l}0.82 \\
0.83\end{array}$ \\
\hline & \multirow{4}{*}{$\begin{array}{l}\text { Organisation } \\
\text { infrastructure }\end{array}$} & Organisation & 0.79 & 0.81 \\
\hline & & Flexibility & 0.80 & 0.82 \\
\hline & & Agility & 0.81 & 0.83 \\
\hline & & Degree of integration & 0.80 & 0.81 \\
\hline & \multirow[t]{6}{*}{ Strategy } & Product differentiation & 0.78 & 0.80 \\
\hline & & Strategic entrepreneurship & 0.79 & 0.83 \\
\hline & & Opportunity seeking & 0.79 & 0.82 \\
\hline & & Advantage seeking & 0.78 & 0.81 \\
\hline & & Niche strategy & 0.80 & 0.82 \\
\hline & & Cost parity & 0.79 & 0.81 \\
\hline 7. & Poverty alleviation & & 0.77 & 0.79 \\
\hline 8. & Wealth distribution & & 0.75 & 0.78 \\
\hline 9. & Wealth motivation & & 0.76 & 0.79 \\
\hline
\end{tabular}


Figure 2: Structural equation modeling: Path dependencies of the variables

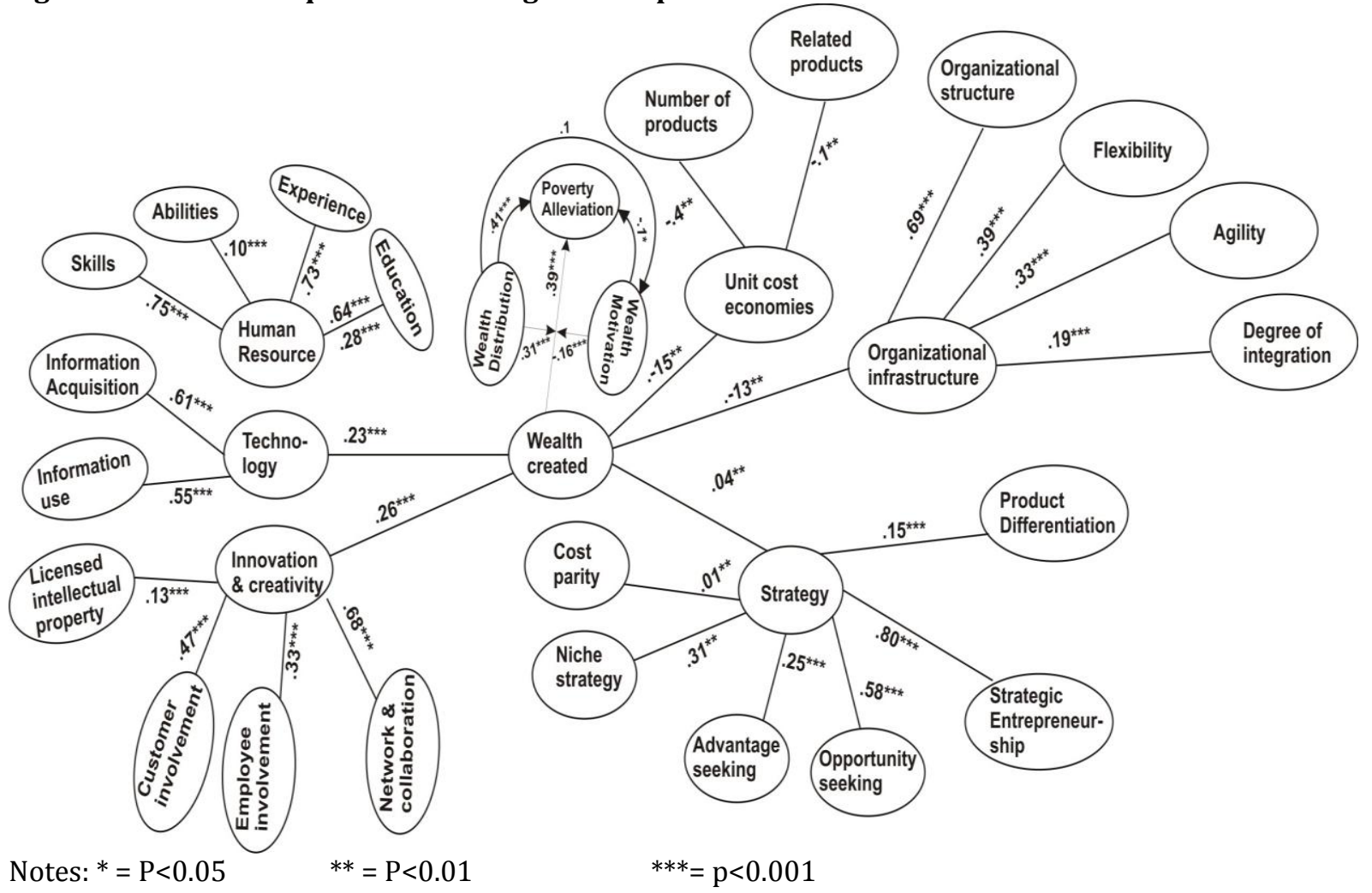

Potential sources of bias: Some major actions taken to reduce the biases in the research design adopted are, firstly, that the CEOs or the most senior executive were requested to complete the questionnaire. Secondly, non-response bias was tested by comparing the early respondents with the late respondents. No significant difference was found because none of the correlations was more than 0.7. Thirdly, multicollinearity was tested for, using the Durbin-Watson test, and 2.28 was obtained, which further indicated that there was no multicollinearity. Lastly, Harman's single-factor test was conducted to test for common method variance. The loading of items on their constructs revealed Eigen values above 1 and the loading of items on their latent factors revealed no significant change in the model fit (CMIN/DF=1.51; CFI=0.91, RMSEA=0.05).

\section{Results and discussion}

Table 2 displays the descriptive statistics and correlation analysis result. 
Table 2: Descriptive statistics and correlation analysis result

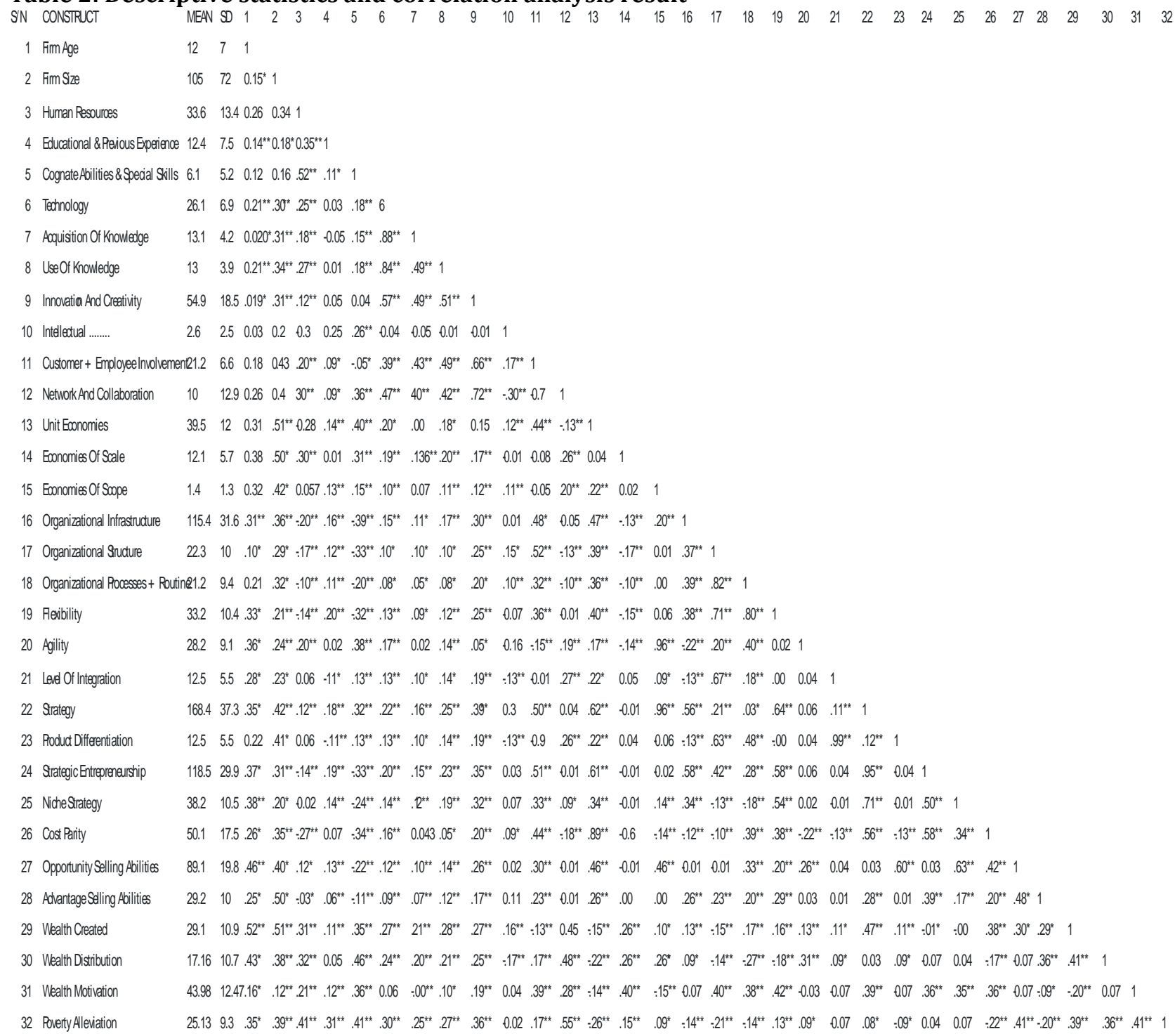

Linear regression was used to test our hypotheses and the standardised coefficients were used to determine the path dependencies in Table III and Figure II respectively.

Human resources: The first model pertained to human resources, with the human resource factors being statistically significant with the wealth created by the firms $(\mathrm{R} 1 \mathrm{a}=0.31)$. The sub-variables of operators' level of education, previous experience, cognate abilities and special skills associated well with wealth creation, hence hypotheses $1 \mathrm{a}, 1 \mathrm{~b}$ and $1 \mathrm{c}$ are supported $(\mathrm{R} 1 \mathrm{~b}=0.11$ and $\mathrm{R} 1 \mathrm{c}=0.35)$, as shown in Table II. The findings of the previous studies of Muller and Gangl (2003), Piva and Vivarelli (2009), and Rosli and Mahmood (2013) were consistent with these findings, in linking educational qualification and skills to different organisational performance indices. This contradicts the findings of Rauch, Frese and Utsch (2005), who believe that organisational performance has little to do with the educational level of the operators. Studies found that association between academic qualification and performance indices did not consider cognate skills and special abilities; hence this study makes a meaningful contribution to the body of knowledge 
Table 3: Regression analysis (Dependent variable: Wealth created)

\begin{tabular}{|c|c|c|c|c|c|c|c|}
\hline Model & 1 & 2 & 3 & 4 & 5 & 6 & 7 \\
\hline Firm age & 0.01 & 0.01 & 0.01 & 0.00 & .00 & .00 & .00 \\
\hline Firm size & -.04 & .03 & .02 & .02 & .03 & .02 & .02 \\
\hline Human resources & $.58^{* *}$ & & & & & & \\
\hline Education & $.64^{*}$ & & & & & & \\
\hline Experience & $.73^{* *}$ & & & & & & \\
\hline Abilities \& skills & $.75^{* *}$ & & & & & & \\
\hline Technology & & $.23^{* *}$ & & & & & \\
\hline Information acquisition & & $.61^{* *}$ & & & & & \\
\hline Information use & & $.55^{* *}$ & & & & & \\
\hline Innovation \& creativity & & & $.18^{* *}$ & & & & \\
\hline Licensed intellectual property & & & $.02^{* *}$ & & & & \\
\hline $\begin{array}{ll}\text { Customer\& } & \text { employee } \\
\text { involvement } & \end{array}$ & & & $.09^{* *}$ & & & & \\
\hline Network \& collaboration & & & $.16^{* *}$ & & & & \\
\hline Unit cost economies & & & & $.08^{* *}$ & & & \\
\hline Number of products & & & & $.06^{* *}$ & & & \\
\hline Product related & & & & $.01^{* *}$ & & & \\
\hline Organisational infrastructure & & & & & $.05^{* *}$ & & \\
\hline Organisational structure & & & & & $.03^{* *}$ & & \\
\hline Flexibility & & & & & $.02^{* *}$ & & \\
\hline Agility & & & & & $.01^{* *}$ & & \\
\hline Degree of integration & & & & & $.01^{*}$ & & \\
\hline Strategy & & & & & & $.03^{* *}$ & \\
\hline Product differentiation & & & & & & $.01^{*}$ & \\
\hline Strategic entrepreneurship & & & & & & $.01 *$ & \\
\hline Opportunity seeking & & & & & & $.01 *$ & \\
\hline Advantage seeking & & & & & & $.01^{\wedge}$ & \\
\hline Niche strategy & & & & & & -.01 & \\
\hline Cost parity & & & & & & $.01^{* *}$ & \\
\hline Poverty alleviation & & & & & & & $.15^{* * *}$ \\
\hline Wealth distribution & & & & & & & $.24^{* * *}$ \\
\hline Wealth motivation & & & & & & & $.16^{* * *}$ \\
\hline Adjusted R-square & $.28^{* *}$ & $-13^{* *}$ & $.14^{* *}$ & $.16^{* *}$ & $.14^{*}$ & $.13^{* *}$ & $.26^{* * *}$ \\
\hline Model f & 47.47 & 31.99 & 40.37 & 11.62 & 17.09 & 13.77 & 68.14 \\
\hline
\end{tabular}

The results are discussed in line with the models in the regression analysis.

Technology adoption: The second model pertained to technology, comprising information acquisition and use. They all have positive and statistical association and path dependencies with wealth creation as depicted in Table II and III as well as Figure II, thus supporting hypotheses $2 \mathrm{a}, 2 \mathrm{~b}$ and $2 \mathrm{c}(\mathrm{R} 2 \mathrm{a}=0.27, \mathrm{R} 2 \mathrm{~b}=0.21, \mathrm{R} 2 \mathrm{C}=$ 0.28). The findings of this study corroborate the outcome of the work of Bako (1991), and Rayport and Sviokia (1990), as well as the philosophical underpinnings of resource based theory of Penrose (1959) who sees knowledge as an intangible resource from which organisation can build competitive advantage.

Innovation and creativity: The next model pertained to innovation and creativity. The results show positive and significant association between the licensed intellectual property and wealth creation as well as customer and employee involvement and wealth creation. As shown in Figure II the associations between these variables and innovation and creativity are high $(r=0.13,0.47,0.33,0.68)$, which suggest that these variables are good measures of innovation and creativity. However, innovation and creativity have positive and significant associations with wealth creation $(\mathrm{R} 3 \mathrm{a}=0.27)$. This result adds credence to the findings in previous research that innovativeness relates positively with firm performance (Chang et al., 2012; Casillas \& Moreno, 2009; Lumpkin \& Dess, 1996). Hypotheses 3a to 3d were therefore supported. 
Unit cost economies: There was a statistically negative association between unit cost economies and wealth creation $(\mathrm{R} 4 \mathrm{a}=-\mathrm{0.15})$ which shows that lower cost economies produces higher wealth, so hypothesis 4a was not supported. However, hypotheses $\mathrm{H} 4 \mathrm{~b}$ and $\mathrm{H} 4 \mathrm{c}$ were supported $(\mathrm{R} 4 \mathrm{~b}=0.26$ significant at both 0.05 and 0.01 levels of significant and $R 4 c=0.10$ significant at only $5 \%$ level of significance). The findings may be premised on the fact that SMEs rarely take full advantage of economies of scale and scope because of the degree of availability of resources. The unit cost economies as an aggregate of economies of scale and economies of scope also show that economy of scale has a stronger relationship with wealth creation than does economy of scope (R4b > R4c). This may be due to frequency of use of the method by the operators because of the level of operation. This was found to affect their level of adoption of cost parity as strategy for competition. This result is supported by Kraus et al. (2011), who observed that SMEs hardly ever achieve cost advantage because they lack some unit cost economies.

Organisational infrastructure: The fifth model revealed a statistically positive association between organisational infrastructure and wealth creation $(\mathrm{R} 5 \mathrm{a}=0.13)$. However, organisational structure related negatively with wealth created $(R 5 b=-0.15)$, which implied that the more sophisticated the structure, the smaller the wealth created by SMEs because of the cost of maintaining such a structure, thus adding credence to simplicity of structure. Flexibility, agility and degree of integration associated positively with wealth creation $(\mathrm{R} 5 \mathrm{c}=0.13, \mathrm{R} 5 \mathrm{~d}=0.16, \mathrm{R} 5 \mathrm{e}=0.13, \mathrm{R} 5 \mathrm{f}=0.11$ ) so hypotheses $\mathrm{H} 5 \mathrm{a}$, and $\mathrm{H} 5 \mathrm{c}$ to $\mathrm{H} 5 \mathrm{f}$ were supported. $14 \%$ of the variations in wealth creation of the SMEs were traceable to the organisational structure (see Table III). This is consistent with the view of Ray et al. (2004) and Clark (1996) that intangible resources that are capable of achieving competitive advantage in operations are premised on the organisational infrastructure.

Strategy: The last model identified the association of the different strategies adopted with wealth created by the SMEs. There was a positive association that was statistically significant between strategy and wealth created $(\mathrm{R} 6 \mathrm{a}=0.47)$. This is the strongest of all the associations, thus revealing the importance of strategy to SMEs' survival. Specifically, the product differentiation, strategic entrepreneurship, cost parity, opportunity seeking and advantage seeking were statistically significant $(\mathrm{R} 6 \mathrm{~b}=0.11, \mathrm{R} 6 \mathrm{c}=0.01, \mathrm{R} 6 \mathrm{e}=0.38, \mathrm{R} 6 \mathrm{f}=0.30$, $R 6 g=0.29$ ), while the niche strategy was not statistically significant (R6d=0.01). So hypothesis $6 \mathrm{~d}$ was the only hypothesis that was not supported. This contradicts the view of Lee \& Tsang (2001) and Bamford et al. (1997) that niche strategy is the special strategy recommended for targeting narrow market by SMEs.

Poverty alleviation: Wealth created by SMEs was responsible for only 15\% variation in poverty alleviation in Nigeria as shown in Table III. Also, poverty alleviation associates well with wealth creation $(R 7=0.39)$ and the association was highly moderated by wealth distribution (R-square change $=.09$; former R-square $=0.15$, the new R-square $=0.24$ ). This supports Anderson's (1964) "trickle-down" theory, while wealth motivation slightly moderated the association (R-square change $=0.01$ ). Hypotheses 7 to 9 were supported $(\mathrm{R} 8=0.36$, $\mathrm{R} 9=0.41$ ) while hypothesis 10 was not supported because a non-statistical relationship exists between wealth distribution and motivation $(\mathrm{R} 10=0.07)$. This implies that people who have a personal motivation to acquire wealth may not be ready to distribute it (Enderle, 2006).

\section{Conclusion}

The study involving 581 CEOs of SMEs in selected states of Nigeria examined a range of determinants of wealth creation and its impact on poverty alleviation. An empirical test of the six domains of SME wealth creation was carried out. The results revealed some significant relationships between the variables of each domain, wealth created as well as poverty alleviation. The data of this study support policy makers by raising contradictions that SME wealth creation could not be explained from firm-level theory. We found that the most important factor that determines SME wealth creation is human resource and strategy. Each of the variables of measure scored high in contributing to the wealth created by firms. These are education, cognate experience, abilities, special skills, product differentiation, cost parity and components of strategic entrepreneurship. This could also explain why firm age was an important moderator in the wealth creation model. Our study thus contradicts past studies that established a negative relationship between experience and firm growth; hence the results of the study are consistent with some leading theories of firm growth. An idea emanating from the findings of the research suggests policy formulation that takes cognisance of the fact 
that wealth is more likely to be created by firms with highly educated CEOs who have special skills and strategic tendencies. The government may need to encourage more graduate apprenticeship schemes. This could birth new firms that would have high propensity of creating wealth.

Firm size is found to relate positively with wealth creation, thus supporting the resource-based view theory. It also suggests a positive relationship between firm size and wealth creation. Technology, innovation and creativity are associated with wealth creation amongst SMEs in Nigeria. The adoption of new technology as well as innovation and creativity help SMEs to face competition and achieve a competitive advantage. This finding was consistent with earlier studies (Bakos, 1991; Casillas \& Moreno, 2009; Lumpkin \& Dess, 1996; Rayport \& Sviokla, 1990). Unit cost economies associate negatively with wealth creation and the path dependencies were negative. It showed that more wealth was created at a lower cost of operations. In a similar trend, cost parity associated positively with wealth creation. In terms of policy implication, government may need to resuscitate the agency in charge of SME development to help the SMEs in an international environmental scanning exercise that would facilitate the acquisition of relevant and effective information that could enhance cost-effective global positioning and material sourcing.

Organisational infrastructure and strategy are important variables to wealth creation. Organisational infrastructure associated positively with wealth creation, but the path dependencies showed a negative trend which inferred that simplicity rather than complex structure is needed for effective wealth creation by SMEs. However, strategy had a much stronger association with wealth created by the firms. Product differentiation and cost parity associate significantly with wealth creation. Poverty alleviation relates well with wealth creation, and the relationship was highly moderated by wealth distribution and lowly by wealth motivation. However, wealth created by the SMEs was only responsible for $15 \%$ variations in poverty alleviation, suggesting a low contribution of SMEs to reducing poverty in Nigeria. The findings also show that the sources of operators' motivation for wealth creation influence the degree of distribution. This finding is the special contribution of this study to the field of SMEs and has great implications for policy makers because poverty can only be alleviated when wealth created is distributed. Such sources of motivation into businesses by entrepreneurs could be used as one of the indicators for qualification for government support.

The key contributions of the study to the body of knowledge are; firstly, it tested the SMEs' Wealth Creation model empirically, secondly; the model was related to poverty alleviation, thirdly; the roles of wealth distribution and motivation were established, fourthly, the model established a positive relationship between experience and firm growth, which is a deviation from the existing knowledge and finally, the study showed the contribution of SMEs to poverty alleviation in Nigeria. In conclusion, this article reported the drivers of SME wealth creation in Nigeria and the relationship with poverty alleviation with 32 variables assessed in structural equation modelling. It was revealed that size and age of firms were significantly related with wealth creation. The study tested empirically the wealth creation model of human resources, technology, innovation and creativity, unit cost economies, organisational infrastructure and strategy domains. All the domains were found to be relevant as determinants of wealth creation. Poverty alleviation related well with wealth creation and the relationship was moderated by wealth distribution and motivation

\section{References}

Adekunle, B. (2011). Determinants of microenterprise performance in Nigeria. International Small Business Journal, 29(4), 360-373.

Almus, M. (2002). What characterises a fast growing firm? Applied Economics, 34(12), 1497-1508.

Analoni, F. \& Karami, A. (2003). Strategic management in small and medium enterprises. London: Thomson.

Anderson, S. \& Tell, J. (2009). The relationship between the manager and growth in small firms. Journal of Small Business and Enterprise Development, 16(4), 586- 598.

Anderson, W. H. L. (1964). Trickling Down, The relationship between economic growth and the extent of poverty of American families. Quarterly Journal of Economics, 78, 511-524.

Asikhia, O. U. (2010). SMEs and Poverty Alleviation in Nigeria: Marketing Resources and Capabilities Implications. New England Journal of Entrepreneurship, 13(2), 57-70.

Asikhia, O. U. (2013.) Poverty alleviation, income redistribution and rural development in developing nations. International Journal of Management Sciences and Humanities, 1(1), 1-12. 
Asikhia, O. U. \& Jansen van Rensburg, M. (2015). SMEs wealth creation model: A conceptual development. African Journal of Hospitality, Tourism \& Leisure, 4(1), 1-19.

Atkinson, A. B. \& Brandolini, A. (2010). On analysing the world distribution of income. Bank of Italy Temi di Discussioni (Working Paper) 701.

Bakos, Y. J. (1991). A strategic analysis of electronic marketplaces. MIS Quarterly, 15(3), 294-310.

Bamford, C. E., Dean, T. J. \& McDougall, P. P. (1997). Initial strategies and new venture growth: an examination of the effectiveness of broad vs. narrow breadth strategies. Frontiers of Entrepreneurship Research, 2, 375-87.

Barkham, R. G., Gudgin, M. \& Hart, M. (1990). The determinants of small firm growth: An inter-regional study in the United Kingdom, 1986-1990. London: Jessica Kingsley Publishers.

Barney, J. B. \& Hesterley, W. S. (2006). Strategic management and competitive advantage concepts. New Jersey: Pearson Prentice Hall.

Bello, B. \& Ivanov, S. (2014). Growth strategies for very small organizations: A cases study of a very small entrepreneurship. The International Journal of Organizational Innovation, 6(4), 51-53.

Bharadwaj, S. \& Menon. A. (2000). Making innovation happen in organizations: Individual creativity mechanisms, organizational creativity mechanism or both? Journal of Production and Innovation Management, 17, 424-34.

Bhuiyan, A. B., Siwar, C., Islam, A. \& Rashid, M. (2012). The approaches of Islamic and conventional microfinancing for poverty alleviation and sustainable livelihood. American Journal of Applied Sciences, 9(9), 1385-1389.

Bhuiyan, A. B., Siwar, C. \& Talib, B. A. (2012). Grameen microcredit and poverty alleviation: A review of Grameen Bank's performance on poverty alleviation in Bangladesh. International Journal of sustainable society, 4(3), 300-315.

Biesebroeck, J. V. (2005). Firm size matters: Growth and productivity in African manufacturing. Economics Development and Culture Change, 53(3), 545-583.

Borch, O. J., Huse, M. \& Senneseth, K. (1979). Resource configuration, competitive strategies, and corporate entrepreneurship: An empirical examination of small firms. Entrepreneurship: Theory \& Practice, 24(1), 49-70.

Brown, J. D., Earle, J. S. \& Lup, D. (2005). What makes small firms grow? Finance, human capital, technical assistance and the business environment in Romania. Economic Development and Culture Change, 54(1), 33-70.

Calori, R. \& Ardisson, J. M. (1988). Differentiation strategies in stalemate industries. Strategic Management Journal, 9, 255-269.

Casillas, J. C. \& Moreno, A. M. (2009). The relationship between entrepreneurial orientation and growth: The moderating role of family involvement. Entrepreneurship \& Regional Development, 22, 265-291.

Cassell, C., Nadin, S., Gray, M. \& Clegg, C. (2002). Exploring human resource management practices in small and medium sized enterprises. Personnel Review, 31(6), 671-692.

Central Bank of Nigeria. (2012). Bulletin. Ikeja: Longman.

Chang, Y. C., Chen, M. H., Lin Y. P. \& Gao, Y. S. (2012). Measuring regional innovation and entrepreneurship capabilities: The case of Taiwan science parks. Journal of Knowledge Economics, 3, 90-108.

Chesbrough, H., (2003). Open innovation: The new imperative for creating and profiting from technology. Boston, MA: Harvard Business School Press.

Chesbrough, H., (2006). Open business models: How to thrive in a new innovation landscape. Boston, MA: Harvard Business School Press.

Clark, K. (1996). Competing through manufacturing and the new manufacturing paradigm: Is manufacturing strategic passé? Production and Operations Management, 5(1), 42-58.

Cravens, D. W. \& Piercy, N. F. (2006). Strategic Marketing. Australia: McGraw-Hill.

Dugguh S. I. (2013). Innovation and business success in Nigeria: from intuition to process management. International Journal of Economics, Commerce and Management, 1(1), 1-8.

EIRMA. (2004). Working Group Report. Belgium: EIRMA.

Enderle, G. (2006). Understanding of "value-free" business in the West. In: Werhane, P. H. and Freeman, R. E. 2005. The Blackwell Encyclopedia of Management. Second Edition. Business Ethics. Malden, MA: Blackwell, 76-80.

Fosu, A. (2010). The effect of income distribution on the ability of growth to reduce poverty: Evidence from rural and urban African economics. American Journal of Economics and Sociology, 69(3), 1034 - 1053. 
Furubotn, E. G. \& Richter, R. (2000). Institutions and Economic Theory: The Contribution of The New Institution Economics. Second Edition. Ann Arbor, MI: The University of Michigan Press.

Garfamy, R. M. (2012). Supply Management: A Transaction Cost Economics Framework. South East European Journal of Economics and Business, 7(2), 139-147.

Gibrat, R. (1931). Les Inegalites Economiques. Paris: Sirey.

Hambrick, D. C. \& Mason, P. A. (1984). Upper echelons: The organization as a reflection of its top managers. Academy of Management Review, 9(2), 193-206.

Hamilton, R. T. (2012). How firms grow and the influence of size and age. International Small Business Journal, 29(3), 278-294.

Hansen, B. \& Hamilton, R. T. (2011). Factors distinguishing small firm growers and non-growers. International Small Business Journal, 30(6), 611-621.

Hitt, M. A., Ireland, R. D., Sirmon, D. G. \& Trahms, C. A. (2011). Strategic entrepreneurship: creating value for individuals, organizations, and society. Academy of Management Perspectives, 25(2), 57-75.

India's SMEs Resource Centre (2012). Small and Medium Scale Enterprises Manual. India: VIS

Ireland, R. D., Hitt, M. A. \& Sirmon, D. G. (2003). A model of strategic entrepreneurship: The construct and its dimensions. Journal of Management, 29(6), 963-89.

Jaquier, B. (2003). Differentiation Strategy. ecofine.com. Retrieved from http://www.ecofine.com/strategy/Differenciation\%20stategy.htm Retrieved on 10/9/2015

Johnson, G. (1990). Managing strategic change: the role of symbolic action, British Journal of Management, $1(1), 183-200$.

Kapurubandara, M. \& Lawson, R. (2006). Barriers to adopting ICT and e-commerce with SMEs in developing countries: An exploratory study in Sri Lanka. University of Western Sydney, Australia.

Keeble, D. (2003). British SMEs in the $21^{\text {st }}$ century: North-south and urban-rural variations in performance and growth. In: Cosh, A. and Hughes, A. (eds). Enterprise Challenged: Policy and Performance in the British SMEs Sector 1999-2002. Cambridge: ESRC Centre for Business Research, University of Cambridge, 87-102.

Kotey, B. (2005). Goals, management practices and performance of family SMEs. International Journal of Entrepreneurial Behaviour and Research, 11(1), 3-24.

Kraus, S., Kauranen, I. \& Reschke, C. H. (2011). Identification of domains for a new conceptual model of strategic entrepreneurship using the configuration approach. Management Research Review, 34 (1), 58-74.

Kuratko, D. F. \& Audretsch, D. B. (2009). Strategic entrepreneurship: exploring different perspectives of an emerging concept. Entrepreneurship Theory and Practice, 33(1), 1-17.

Lee, D. Y. \& Tsang, E. W. K. (2001). The effects of entrepreneurial personality, background and network activities on venture growth. Journal of Management Studies, 38(4), 583-602.

Lee, K. S., Lim, G. H., Tan, S. J. \& Wee, C. H. (2001) Generic Marketing Strategies for Small Business. Singapore: Free Press

Lumpkin, G. T. \& Dess, G. G. (1996). Clarifying the entrepreneurial orientation construct and linking it to performance. Academy of Management Review, 21 (1), 135-172.

Makadok, R. (2001). Toward a synthesis of the resource-based and dynamic-capability views of rent creation. Strategic Management Journal, 22(5), 387-402.

McClelland, D. C. (1961). Achieving society. New York: The Free Press.

Meyer, J. W. \& Rowan, B. (1977) Institutional organizations: Formal structure as myth and ceremony, American Journal of Sociology, 83, 340-63.

Minarik, M. (2007). Cost leadership and differentiation: An investigation of the fundamental trade-off between Porter's cost leadership and differentiation strategies. MSc Thesis in International Business, Stockholm School of Business.

Muller, W. \& Gangl, M. (2003). Transitions from education to work in Europe. Oxford: Oxford University Press.

Newbert, S. (2007). Empirical research on the resource-based view of the firm: An assessment and suggestions for future research. Strategic Management Journal, 28, 121-146.

Nooteboom, B. (1993). Service value chains and effect of scale. Service Business, 1, 119-139.

OECD. (2002). Annual Report 2002.

OECD. (2006). Annual Report 2006.

Pender, J., Alexander, M. and Reeder, R. (2012). Rural wealth creation: Concepts, strategies and measures. Economic Research Report, 131, 1-87. 
Penrose, E. (1959). Theory of the growth of the firm. Oxford: Basil Blackwell, Oxford.

Pietrobelli, C. (2006). Fostering technological capabilities in Sub-Saharan Africa. Science and Development Network. http://www.scidev.net/en/policy-briefs, retrieved on 06/09/15.

Pitelis, C. N. \& Vasilaros, V. (2009). The determinants of value creation at the firm, industry and national levels. A framework and evidence. Dynamic Regions in a Knowledge-Driven Global Economy Lessons and Policy Implications for EU (DYNREG) Working Papers, 1-45

Piva, M. \& Vivarelli, M. (2009).The role of skills as a major driver of corporate R\&D. International Journal of Manpower, 30(8), 835-852.

Porter, M. (1996). What is strategy? Harvard Business Review, 10(11), 60-80.

Powell, W. W. (1990). Neither market nor hierarchy: network forms of organization. In Staw, B. M. \& Cummings, L. L. (eds). Research in Organizational Behavior (Volume 12). Greenwich, CT: JAI Press, 295-336.

Rauch, A., Frese, M. \& Utsch, A. (2005). Effects of human capital and long-term human resources development and utilization of employment growth of small-scale businesses: A causal analysis. Entrepreneurship Theory and Practice, 29(6), 681-698.

Rayport, J. F. \& Sviokla, J. J. (1990). Managing in the market place. Harvard Business Review, 11 (November/ December), 2-11.

Robbins, S. (2000). Essential of organization behavior, 6th ed. Englewood Cliffs, NJ: Prentice-Hall.

Roodman, D. \& Morduch, J. (2009). The Impact of Microcredit on the Poor in Bangladesh: Revisiting the Evidence. Centre for Global Development, Working Paper Number 174.

Rosli, M. M. \& Mahmood, R. (2013). Moderating effect of human resource practices and entrepreneur training on innovation and small-medium firms' performance. Journal of Management and Strategy, 4(2), 6069.

Santos-Pautino, A. U. (2012). Trade, income distribution and poverty in developing countries: survey. United Nations Conference on Trade and Development (UNITAD) Discussion Paper, 1-39.

Schumpeter, J. (1934). The Theory of Economic Development. Cambridge, MA: Harvard University Press.

Shaver, K. G. \& Scott, L. R. (1991). Person, process, choice: The psychology of new venture creation. Entrepreneurship Theory and Practice, winter, 23-47.

Storey, D. J. (2004). Exploring the link, among small firms, between management training and firm performance: A comparison between the UK and other OECD countries. International Journal of Human Resource Management, 15(1), 112-30.

Sutton, J. (1990) Gibrat's legacy. Journal of Economic Literature, 35, 40-59.

Teece, D. \& Pisano, G. (1994). The dynamic capabilities of firms: An introduction. Industrial and Corporate Change, 3(3), 537-556.

Thaennin, N., Visuthismajam, P. \& Sutheravut, P. (2012). Participation in agri-food safety collaborative network: An example from Songkhla province, Thailand. International Journal of Management \& Information Systems, 16(4), 331-339.

Tovar, B. \& Wall, A. (2012). Economies of scale and scope in service firms with demand uncertainty: An application to a Spanish port. Maritime Economics \& Logistics, 14 (3), 362-385.

UNIDO. (2012). Annual Report 2012.

UNIDO-Nigeria. (2012). Annual Report 2012.

Uzzi, B. (1997). Social structures and competition in inter-firm networks: The paradox of embeddedness. Administrative Science Quarterly, 42(1), 35- 68.

Walton R. T., Akselsen, S. \& Pitt, L. F. (1998). Attractors: Building mountains in the flat landscape of the world wide web. California Management Review, 40(2), 36-57.

Wickham, P. A. (2006). Strategic entrepreneurship (4th ed.). London: Prentice Hall.

Willamson, O. E. (1975). Markets and Hierarchies. New York: Free Press.

Willamson, O. E. ( 1979). Transaction cost economies: The governance of contractual rule. The journal of law \& economics, 22(2), 233-261.

Willamson, O. E. ( 1981). The economics of organization: The transaction cost approach. The American Journal of Sociology, 87(3), 548-577.

World Bank. (2014). World Development Report, New York: Free Press 